\title{
SISTEM PAKAR PENDIAGNOSA PENYAKIT GINJAL
}

\author{
Luther Latumakulita $^{1)}$, Chriestie E. J. C. Montolalu ${ }^{1)}$ \\ alexalatu@gmail.com \\ ${ }^{1)}$ Program Studi Matematika FMIPA Universitas Sam Ratulangi
}

\begin{abstract}
ABSTRAK
Sistem pakar merupakan salah satu cabang kecerdasan buatan yang mempelajari bagaimana meniru cara berpikir seorang pakar dalam menyelesaikan suatu permasalahan. Kecerdasan buatan adalah salah satu bidang ilmu komputer yang mendayagunakan komputer sehingga dapat berperilaku cerdas seperti manusia. Ilmu komputer mengembangkan perangkat lunak dan perangkat keras untuk menirukan tindakan manusia. Aktifitas manusia yang ditirukan seperti penalaran, penglihatan, pembelajaran, pemecahan masalah, pemahaman bahasa alami, dan sebagainya. Sesuai definisi, teknologi kecerdasan buatan dipelajari dalam bidang-bidang seperti Robotika (Robotics), Penglihatan Komputer (Computer Vision), Pengolahan Bahasa Alami (Natural Language Processing), Pengenalan Pola (Pattern Recognition), Sistem Syaraf Buatan (Artificial Neural System), Pengenalan Suara (Speech Recognition), dan Sistem pakar (Expert System). Sistem pakar terdiri 2 bagian pokok, yaitu lingkungan pengembangan (development environment) digunakan sebagai pembangun sistem pakar baik dari segi pembangun komponen maupun basis pengetahuan dan lingkungan konsultasi (consultation environment)digunakan oleh seseorang yang bukan ahli untuk berkonsultasi. Lingkungan pengembangan digunakan oleh ES builder untuk membangun komponen dan memasukan penetahuan kedalam basis pengetahuan. Aplikasi Sistem Pakar ini adalah merupakan paket perangkat lunak yang membahas bagaimana cara untuk mendeteksi penyakit ginjal pada manusia. Sistem pakar pendeteksi penyakit ginjal pada manusia ini terdiri atas 2 bagian yaitu : Lingkungan Konsultasi (Development environment) dan Lingkungan Pengembangan (Consultation environment). Bahasa pemrograman yang digunakan untuk membuat aplikasi system pakar ini Microsoft Visual Studio 6.0 dengan databasenya menggunakan Microsoft Access 2003. sesuai dengan bahasa pemrograman yang digunakan maka interface yang akan ditampilkan dalam memberikan informasi bagi user akan berbentuk visual.
\end{abstract}

Kata kunci: penyakit ginjal, sistem pakar

\section{EXPERT SYSTEM FOR KIDNEY DISEASE DIAGNOSIS}

\begin{abstract}
Expert System (ES) is an artifial intelligence which aplicate a profesional's way of think in solving a problem. Artificial intelligence is a computer field which move computer to operate as smart as human brain. This computer science develop software and hardware to act like a human. Human activities which modify such as reasoning, vision, learning, problem solving, natural language, etc. Base on that definition, artificial intelligence technologi were improved in many fields such as Robotics, Computer Vision, Natural Language Processing, Pattern Recognition, Artificial Neural System, Speech Recognition, and Expert System. Expert System consist of two main fields: development environment used as expert system builder in component builder and also knowledge base, and consultation builder used by a person who has not ability in in consultation. Development environment used by ES builder to build component and input knowledge in to the knowledge base. This Expert System Aplication is a software sistem, which improve the aplication to detect kidney disease for human. Expert System detection of kidney disease for human consists of two parts: Development environment and Consultation environment.Programming language, which used to build this Expert System aplication, is Microsoft Visual Studio 6.0 with database Microsoft Access 2003. Base on the language programming used, then the interface, to give the information for user, will be shown in visual.
\end{abstract}

Keywords: kidney disease, expert system 


\section{PENDAHULUAN}

\section{Latar Belakang}

Seiring dengan perkembangan zaman dan teknologi, peran komputer semakin mendominasi kehidupan umat manusia dalam melakukan suatu pekerjaan. Komputer tidak lagi hanya digunakan sebagai alat hitung, namun komputer diharapkan agar dapat mengerjakan segala sesuatu yang biasa dikerjakan oleh manusia.

Manusia bisa menyelesaikan masalah karena manusia mempunyai pengetahuan dan pengalaman. Pengetahuan diperoleh dengan belajar, semakin banyak belajar tentu saja pengetahuan seseorang akan meningkat sehingga memiliki kemampuan dalam meyelesaikan masalah. Tanpa memiliki kemampuan untuk menalar dengan baik Manusia dengan segudang pengalaman dan pengetahuan tidak akan dapat menyelesaikan masalah dengan baik.

Untuk itu agar komputer dapat melakukan tindakan seperti dan sebaik manusia, maka komputer juga harus diberi bekal pengetahuan dan mempunyai kemampuan untuk menalar. Sistem pakar adalah merupakan salah satu cabang kecerdasan buatan yang mempelajari bagaimana meniru Cara berpikir seorang pakar dalam menyelesaikan suatu permasalahan. Membuat keputusan maupun mengambil kesimpulan sejumlah fakta. Kajian pokok dalam system pakar adalah bagaimana mentransfer pengetahuan yang dimiliki oleh seorang pakar kedalam komputer dan bagaimana mengambil keputusan dan juga mengambil kesimpulan berdasarkan pengetahuan itu. Dengan menyimpan informasi dan digabungkan dengan himpunan aturan penalaran yang memadai memungkinkan komputer memberikan kesimpulan atau mengambil keputusan seperti seorang pakar.maka penulis membuat system pada komputer yang bisa menyelesaikan masalah dan memberikan solusi tentang bagaimana mendeteksi penyakit ginjal sejak dini pada manusia.

\section{Identifikasi Masalah}

Dilihat dari pentingnya ginjal dalam tubuh manusia yang merupakan organ vaskular (kaya pembuluh darah), maka penulis memandang perlu adanya suatu pendeteksi dalam memecahkan suatu masalah mengenai penyakit ginjal yang menyerang manusia.

\section{TINJAUAN PUSTAKA}

\section{Sistem Pakar}

Konsep dasar sistem pakar mengandung keahlian, ahli, pengalihan keahlian, inferensi, aturan, dan kemampuan menjelaskan.

Keahlian adalah suatu kelebihan penguasaan pengetahuan di bidang tertentu yang diperoleh dari pelatihan, membaca atau pengalaman. Contoh bentuk pengetahuan yang termasuk keahlian:

- Fakta- fakta pada lingkup permasalahan tertentu.

- Teori-teori pada lingkup permasalahan tertentu.

- Prosedur-prosedur dan aturan-aturan berkenaan dengan lingkup permasalahan tertentu.

- Strategi-strategi global untuk menyelesaikan masalah.

- Meta-Knowledge (pengetahuan tentang pengetahuan).

Bentuk-bentuk ini memungkinkan para ahli untuk dapat mengambil keputusan lebih cepat dan lebih baik daripada seseorang yang bukan ahli. (Turban, 1995)

\section{Kecerdasan Buatan}

Kecerdasan buatan atau artificial intelligence merupakan salah satu bagian ilmu komputer yang membuat agar mesin ( komputer ) dapat melakukan pekerjaan seperti dan sebaik yang dilakukan oleh manusia. Kecerdasan buatan dapat dipandang dari berbagai sudut pandang, antara lain :

1. Sudut pandang kecerdasan

Kecerdasan buatan akan membuat mesin menjadi 'cerdas' ( mampu berbuat seperti apa yang dilakukan oleh manusia )

2. Sudut pandang penelitian

Kecerdasan buatan adalah suatu studi bagaimana membuat agar komputer dapat melakukan sesuatu sebaik yang dikerjakan oleh manusia (Kusumadewi, 2003).

\section{Pengertian Data Base}

Data base adalah suatu kumpulan data yang terintegrasi yang diorganisasikan untuk memenuhi kebutuhan para pemakai didalam suatu organisasi. semua pengaksesan kedata base ditangani oleh suatu piranti lunak yang 
disebut database management system. Data base merupakan himpunan kelompok kata yang saling berkaitan. Data tersebut diorganisasikan sedemikian rupa agar tidak terjadi duplikasi yang tidak perlu, sehingga dapat diolah atau dieksplorasi secara cepat dan mudah untuk menghasilkan informasi.

Secara fisik suatu data base terdiri atas entity-entity yang biasanya disebut table. Tiap-tiap table tersebut mempunyai atributatribut yang disebut field. Dan isi dari table tersebut disebut tuple atau record yang merupakan tumpukan baris yang mempunyai minimal satu atribut dari table tersebut.

Database rasional adalah salah satu data base yang sering digunakan dan tersedia untuk aplikasi komputer yang penting. Database relasional menyediakan sebuah kemampuan yang sangat kuat dan fleksibel untuk menyimpan data dari berbagai jenis (Kristanto, 2000).

\section{Analisa dan Perancangan Sistem}

Aplikasi Sistem Pakar ini adalah merupakan paket perangkat lunak yang membahas bagaimana cara untuk mendeteksi penyakit ginjal pada manusia. Sistem pakar pendeteksi penyakit ginjal pada manusia ini terdiri atas 2 bagian yaitu : Lingkungan Pengembangan (Development environment) dan Lingkungan Konsultasi (Consultation environment)

\section{Konsep Dasar Pengembangan Sistem.}

Untuk membangun aplikasi system pakar ini melalui beberapa tahapan pengembangan antara lain :

1. Menentukan bahasa pemrograman yang akan digunakan.

2. Analisa system

3. Desain Sistem.

4. Prototype dasar kasus

\section{Menentukan bahasa pemrograman.}

Bahasa pemrograman yang digunakan untuk membuat aplikasi system pakar ini Microsoft Visual Studio 6.0 dengan databasenya menggunakan Microsoft Access 2003. sesuai dengan bahasa pemrograman yang digunakan maka interface yang akan ditampilkan dalam memberikan informasi bagi user akan berbentuk visual.

\section{Identifikasi Masalah}

Identifikasi dilakukan dengan menggambarkan proses yang terjadi pada aplikasi system pakar yang dibangun secara keseluruhan. Proses tersebut antara lain:

1. User memberikan informasi gejala suatu penyakit.

2. Aplikasi akan melakukan pengecekan pada basis data/database.

3. Proses pengolahan data dilakukan dengan mengindetifikasi permasalahan dengan menentukan macam dan jenis gejala.

4. Menentukan/mendeteksi berapa persen mengidap penyakit ginjal pada manusia.

User yang ingin mengetahui gejala yang menimbulkan penyakit ginjal harus memasukan informasi berupa data - data gejala, jenis dan ciri penyakit yang di derita. Proses indentifikasi akan dimulai dengan akuisisi pengetahuan (Knowladge Acquisition) dilanjutkan dengan representasi pengetahuan (Knowledge reperesetation).

\section{Akuisisi Pengetahuan (Knowledge Acquisition).}

Akuisisi Pengetahuan merupakan proses untuk mengumpulkan data - data pengetahuan akan suatu masalah dari pakar. bahan pengetahuan dapat ditempuh dengan beberapa cara, misalnya mendapat pengetahuan dari buku, jurnal, ilmiah, para pakar dibidangnya, laporan, literature, dan seterusnya. Sumber pengetahuan tersebut dijadikan dokumentasi untuk dipelajari, diolah dan diorganisasikan secara terstruktur menjadi basis pengetahuan.

Akuisisi pengetahuan pendeteksi penyakit ginjal sejak dini dengan mengumpulkan data tentang ciri - ciri, jenis serta gejala-gejala penyakit. Data tentang penyakit ginjal pada manusia ini diperoleh dari ahli dibidangnya, referensi dari buku dan juga internet.

\section{Daftar Penyakit Ginjal Pada Manusia}

$\mathrm{A}=$ Penyakit Gagal Ginjal Akut; B=Penyakit Gagal Ginjal Akut Kronik; C=Penyakit Nefritis Akut; $\mathrm{D}=$ Penyakit Nefropati Diabetik;E= Penyakit Infeksi Saluran Kemih; F= Penyakit Batu Ginjal; $\mathrm{G}=$ Penyakit Pielonefritis; $\mathrm{H}=$ Penyakit tuberkolosis ginjal; I=Penyakit Obstruksi Saluran Kemih; J=Penyakit Glomerulonefritis akut; J=Penyakit Glomerulonefritis kronk; $\mathrm{K}=$ Penyakit Nefroskelerosis; L=Penyakit Batu Ureter; $\mathrm{M}=$ Penyakit Tumor ginjal; $\mathrm{N}=$ Penyakit Nekrosis Tubuler Aku 
Tabel Keputusan

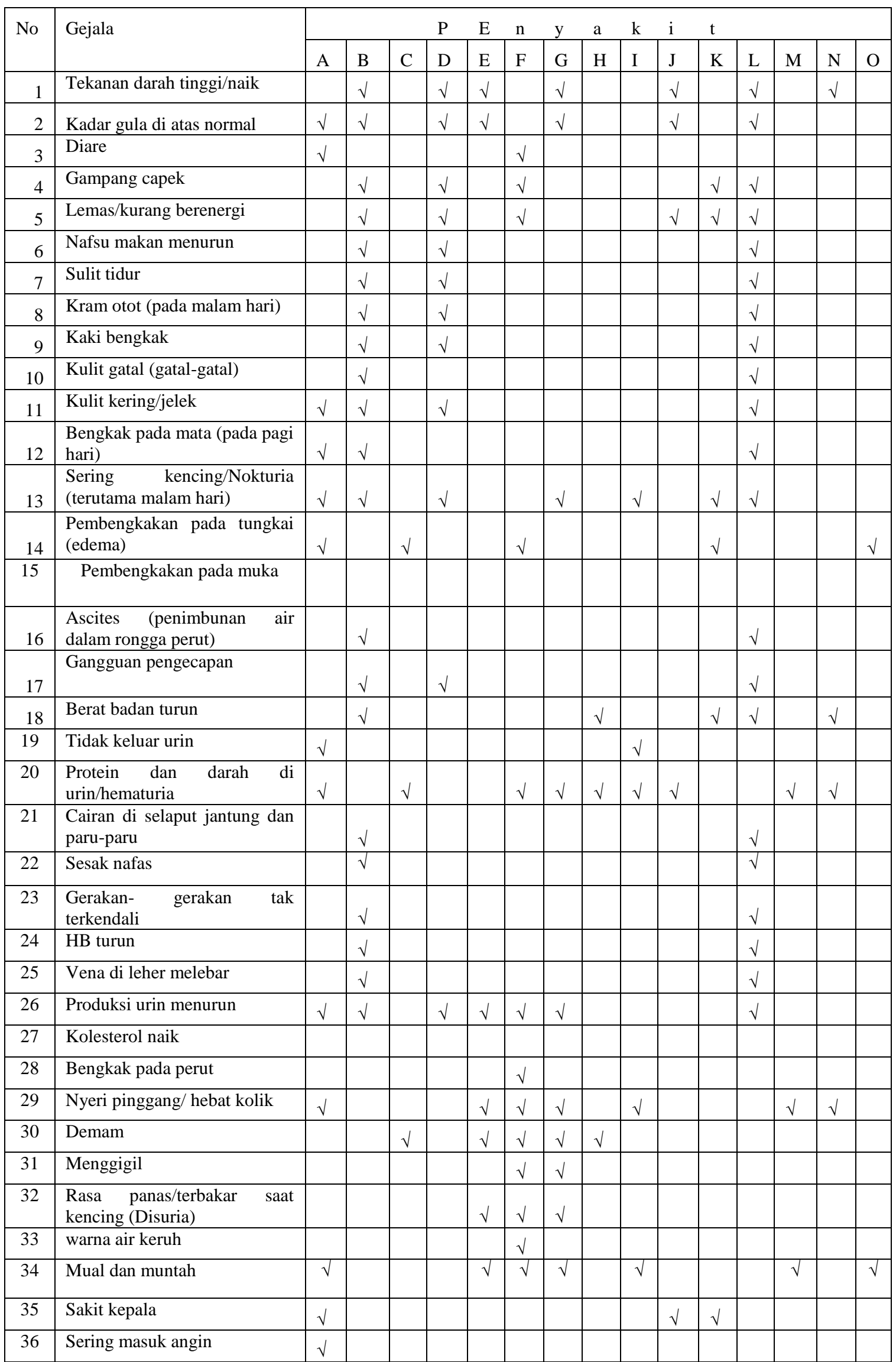




\begin{tabular}{|c|c|c|c|c|c|c|c|c|c|c|c|c|c|c|c|c|}
\hline 37 & Sering cegukan & $\sqrt{ }$ & & & & & & & & & & & & & & \\
\hline 38 & $\begin{array}{ll}\text { urgensi/ merasa } & \text { harus } \\
\text { berkemih segera } & \\
\end{array}$ & & & & & $\sqrt{ }$ & & $\sqrt{ }$ & & $\sqrt{ }$ & & & & & & \\
\hline 39 & Penurunan kesadaran & $\sqrt{ }$ & & & & & $\sqrt{ }$ & & $\sqrt{ }$ & & & & $\sqrt{ }$ & & & $\sqrt{ }$ \\
\hline 40 & Kejang - kejang & & $\sqrt{ }$ & & & & & & & & & & $\sqrt{ }$ & & & \\
\hline 41 & Kencing Keluar batu/pasir & & & & & & $\sqrt{ }$ & & & & & & & $\sqrt{ }$ & & \\
\hline 42 & $\begin{array}{l}\text { Nyeri di daerah kemaluan dan } \\
\text { selangkangan }\end{array}$ & & & & & & $\sqrt{ }$ & & & & & & & & & \\
\hline 43 & Nafas bau & $\sqrt{ }$ & & & & & & & & & & & & & & $\sqrt{ }$ \\
\hline 44 & $\begin{array}{l}\text { Sesuatu yabg asing dalam } \\
\text { kandung kemih }\end{array}$ & & & & & & & & & & & & & & & \\
\hline 45 & Nyeri saat buang air kecil & & & & & $\sqrt{ }$ & & $\sqrt{ }$ & & & & & & & & \\
\hline 46 & $\begin{array}{l}\text { Buang air } \\
\text { merah/berdarah }\end{array}$ & & & & & & $\sqrt{ }$ & & & & & & & & & \\
\hline 47 & Bekuan darah & & & & & & $\sqrt{ }$ & & & & & & & & & \\
\hline 48 & Nyeri perut & & & & & & $\sqrt{ }$ & & & & & & & $\sqrt{ }$ & & \\
\hline 49 & Sukar berkonsentrasi & & $\sqrt{ }$ & & $\sqrt{ }$ & & $\sqrt{ }$ & & & & & & & & & \\
\hline 50 & Pegal pinggang/panggul & & & & & $\sqrt{ }$ & & $\sqrt{ }$ & & & $\sqrt{ }$ & & & & $\sqrt{ }$ & \\
\hline 51 & nyeri tekan di area ginjal & & & & & $\sqrt{ }$ & & $\sqrt{ }$ & & $\sqrt{ }$ & & & & $\sqrt{ }$ & & \\
\hline 52 & $\begin{array}{l}\text { Oliguria(urine keluar }< \\
400 \mathrm{ml} / 24 \mathrm{jam}\end{array}$ & $\sqrt{ }$ & & $\sqrt{ }$ & & $\sqrt{ }$ & & $\sqrt{ }$ & & & & & & & & $\sqrt{ }$ \\
\hline 53 & $\begin{array}{l}\text { Bau air kencing yang lebih } \\
\text { menyengat }\end{array}$ & & & & & & $\sqrt{ }$ & & & & & & & & & \\
\hline 54 & Pucat/anemia & $\sqrt{ }$ & $\sqrt{ }$ & & & & & & & & & & $\sqrt{ }$ & & & $\sqrt{ }$ \\
\hline 55 & Reaksi Alergi & & & & & & & & & & & & & & & \\
\hline 57 & Penglihatan kabur & & & & & & & & & & & $\sqrt{ }$ & & & & \\
\hline 58 & $\begin{array}{lll}\text { Dispnea } & \text { waktu melakukan } \\
\text { kegiatan } & & \end{array}$ & & & & & & & & & & & $\sqrt{ }$ & & & & \\
\hline 59 & Sulit berkemih & & & & & & & & & & & & & & & \\
\hline 60 & $\begin{array}{ll}\text { Massa di } & \text { sudut } \\
\text { kostovertebrata }\end{array}$ & & & & & & & & & & & & & & $\sqrt{ }$ & \\
\hline 61 & kulit mudah lecet & & $\sqrt{ }$ & & & & & & & & & & & & & \\
\hline 62 & insomnia & & $\sqrt{ }$ & & $\sqrt{ }$ & & & & & & & & & & & \\
\hline 63 & impotensi & & $\sqrt{ }$ & & & & & & & & & & & & & \\
\hline 64 & Bingung & & $\sqrt{ }$ & & $\sqrt{ }$ & & & & & & & & & & & $\sqrt{ }$ \\
\hline 65 & $\begin{array}{l}\text { Urea frost(kristalisasi urea } \\
\text { pada kulit) }\end{array}$ & & $\sqrt{ }$ & & & & & & & & & & & & & \\
\hline 66 & Kelemahan otot- otot & & $\sqrt{ }$ & & $\sqrt{ }$ & & & & & & & & & & & \\
\hline 67 & nyeri ketok pada pinggang & & & & & & & $\sqrt{ }$ & & & & & & & & \\
\hline 68 & Perdarahan & & & & & & & & & & & & & $\sqrt{ }$ & $\sqrt{ }$ & \\
\hline 69 & Haus/ dehidrasi & $\sqrt{ }$ & & & & & & & & & & & & & & $\sqrt{ }$ \\
\hline 70 & Nafsu seks menurun & & $\sqrt{ }$ & & & & & & & & & & & & & \\
\hline 71 & Berak Darah & $\sqrt{ }$ & & & & & & & & & & & & & & \\
\hline 72 & Payah jantung & $\sqrt{ }$ & & & & & & & & & & & & & & \\
\hline 73 & $\begin{array}{l}\text { Pusing pada setiap perubahan } \\
\text { posisi tubuh }\end{array}$ & $\sqrt{ }$ & & & & & & & & & & & & & & \\
\hline
\end{tabular}

(Sumber Mary Baradero, SPC, MN,2009. “Seri Asuhan Keperawatan Klien Gangguan Ginjal”,Penerbit Buku Kedokteran) 


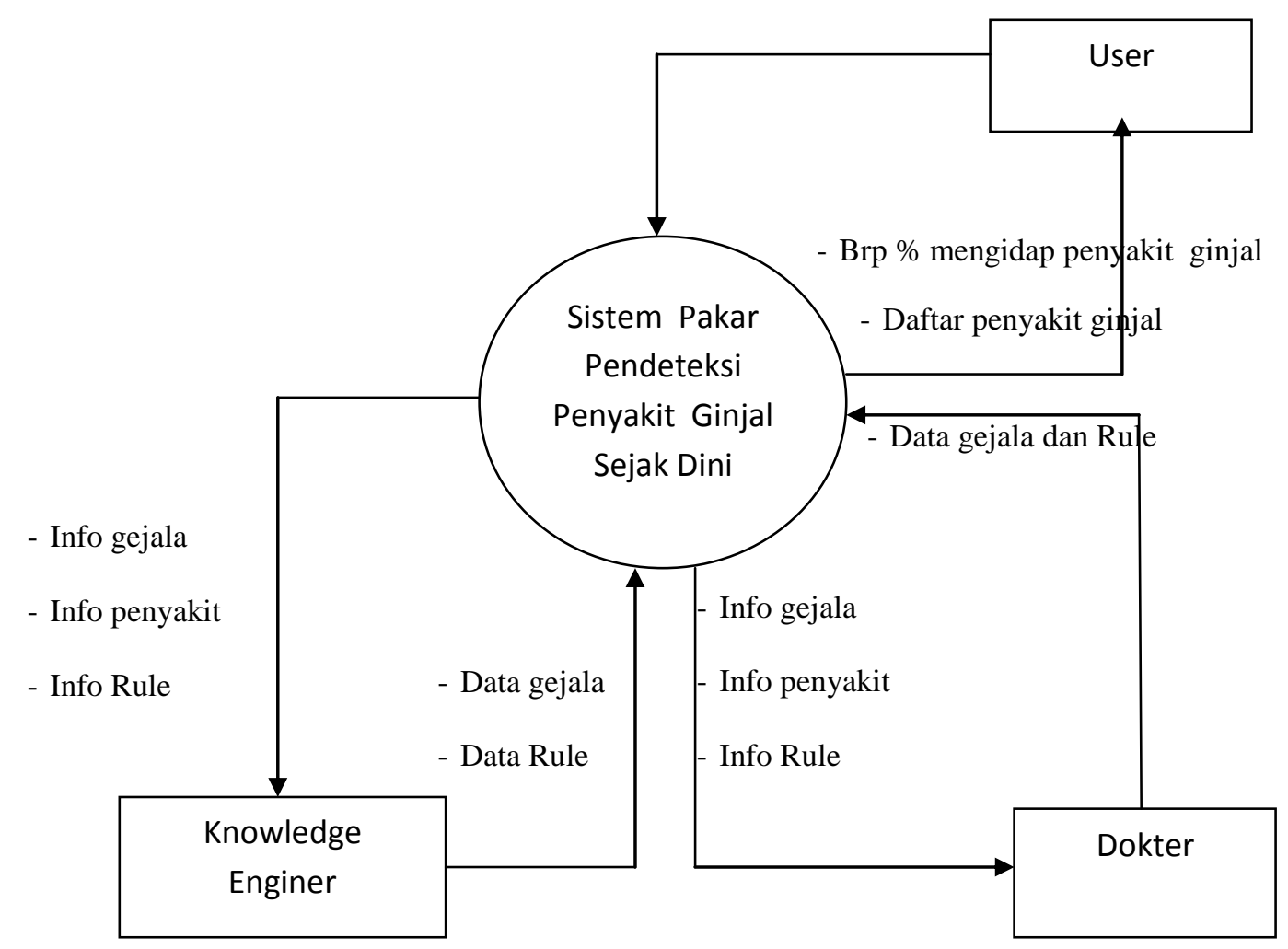

Gambar 1. Flow Diagram Pendeteksi Penyakit Ginjal Pada Manusia (DFD) 


\section{Bisnis Rule}

Seseorang bisa mengidap lebih dari satu gejala dan penyakit.

$>$ Satu gejala bisa di mliki oleh beberapa penyakit.

$>$ Pengetahuan dapat di tambah berdasarkan hak atas knowledge enginer.

$>$ Seseorang dapat mendeteksi penyakit lebih dari satu kali.

\section{$>$ Rule}

Pada aturan 1 (Rule 1) berdasarkan tabel keputusan di atas, maka aturan yang di gunakan untuk penyakit Gagal Ginjal Akut :

IF Tekanan darah tinggi

AND Kadar gula di atas normal

AND Kulit Kering jelek

AND Bengkak pada mata

AND Sering kencing Nokturia

AND Pembengkakan pada tungkai Edema

AND Tidak keluar urin

AND Hematuria

AND Produksi urin menurun

AND Nyeri pinggang hebat kolik

ANd Mual muntah

AND Sakit kepala

AND Sering Masuk Angin

AND Sering cegukan

AND Penurunan kesadaran

AND Nafas Bau

AND Oliguria

AND Pucat anemia

AND Haus Dehidrasi

AND Berak darah

AND Payah jantung

AND Pusing pada setiap posisi tubuh

THEN Gagal Ginjal Akut

Pada aturan 2 (Rule 2) berdasarkan tabel keputusan dapat di tentukan aturan untuk penyakit Gagal Ginjal Kronik :

IF Tekanan darah tinggi

AND Kadar gula di atas normal

AND Gampang capek

AND Lemas/kurang berenergi

AND Nafsu makan menurun

AND Sulit tidur

AND Kram otot pada malam hari

AND Kaki bengkak

AND Kulit gatal/gatal-gatal

AND Kulit kering/jelek

AND Bengkak pada mata

AND Sering kencing/nokturia

AND Pembengkakan pada tungkai/edema
AND Ascites/penimbunan air dalam rongga perut

AND Gangguan pengecapan

AND Berat badan turun

AND Cairan selaput dijantung

AND Sesak nafas

AND Gerakan-gerakan tak terkendali

AND Kelainan urin

AND HB turun

AND Vena di leher melebar

AND Produksi urin menurun

AND Kejang-kejang

AND Sukar berkonsentrasi

AND Pucat/anemia

AND Kulit mudah lecet

AND Insomnia

AND impotensi

AND Bingung

AND Urea frost/kristalisasi urea pada kulit

AND Kelemahan otot-otot

AND Nafsu seks menurun

THEN Gagal Ginjal Kronik

Pada aturan 3 (rule 3) berdasarkan tabel

keputusan, atuaran yang dapat di gunakan

untuk Penyakit Nefritis Akut:

IF Pembengkakan pada tungkai/Edema

AND Protein dan darah di urin/hematuria

AND Demam

AND Oliguria/Urine keluar $<400 \mathrm{ml}$ per 24 jam

THEN Nefritis Akut

Pada aturan 4(Rule 4) berdasarkan tabel keputusan dapat di gunakan aturan untuk penyakit Nefropati Diabetik:

IF Tekanan darah tinggi/naik

AND Kadar gula di atas normal

AND Gampang capek

AND Lemas/kurang berenergi

AND Nafsu makan menurun

AND Sulit tidur

AND Kram otot pada malam hari

AND Kaki bengkak

AND Kulit kering/jelek

AND Sering kencing/nokturia

AND Gangguan pengecapan

AND Kelainan urin

AND Produksi urin menurun

AND Sukar berkonsentrasi

AND Insomnia

AND Bingung

AND Kelemahan otot-otot

THEN Nefropati Diabetik 
Aturan 5 (Rule 5) berdasarkan tabel keputusan dapat digunakan aturan untuk Penyakit Infeksi Saluran Kemih:

IF Tekanan darah tinggi/naik

AND Kadar gula di atas normal

AND Produksi urin menurun

AND Nyeri pinggang/hebat kolik

AND Demam

AND Rasa panas/terbakar saat

kencing(Disuria)

AND Mual dan muntah

AND Urgensi/merasa harus berkemih segera

AND Nyeri saat buang air kecil

AND Pegal pinggang/panggul

AND Nyeri tekan di area ginjal

AND Oliguria(urine keluar $<400 \mathrm{ml} / 24 \mathrm{jam}$

THEN Infeksi saluran kencing kemih

\section{HASIL DAN PEMBAHASAN}

Implementasi penelitian ini dapat dilihat pada capture-capture form berikut ini

\section{Form Menu Utama}

Menu utama sebagai user interface yang muncul pertama kali pada saat aplikasi dijalankan dan dapat dilahat pada gambar 2 .

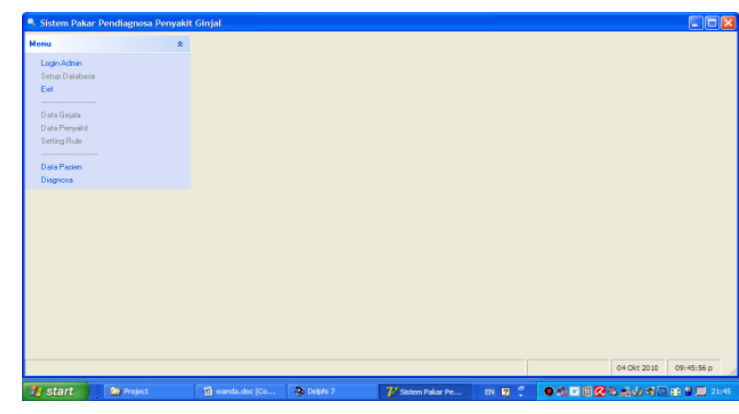

Gambar 2. Form Menu Utama

\section{Form Login}

Form login digunakan untuk mengakses program sehingga user yang berhak saja yang dapat mengakses aplikasi ini. Form logindapat dilihat pada gambar 3 .

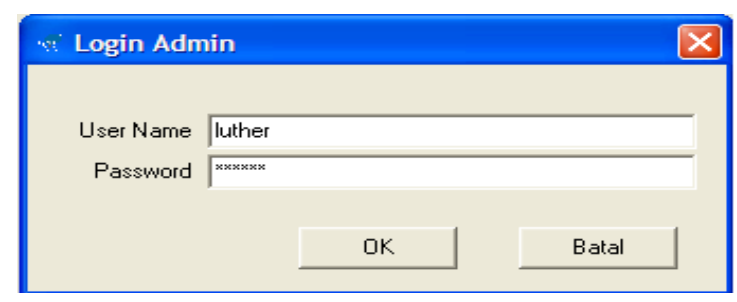

Gambar 3. Form Login

\section{Form Setup Database}

Form setup database digunakan untuk megarahkan path pada folder dimana database tersimpan. Form ini dapat dilihat pada gambar 4.

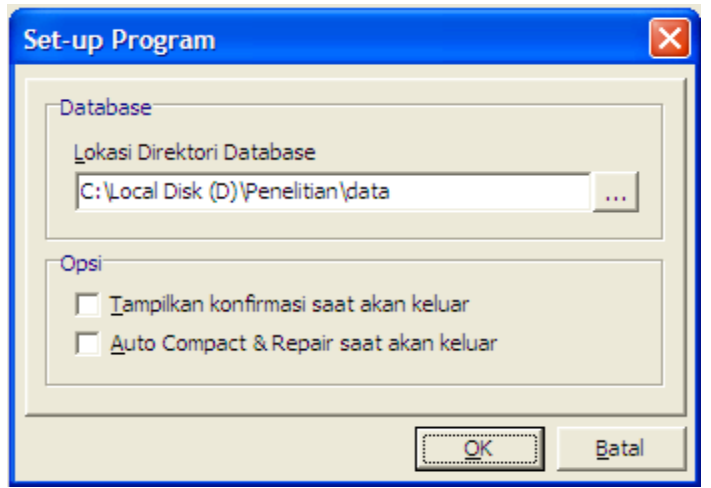

Gambar 4. Form Setup Database

Form Penginputan Gejala Penyakit Ginjal Form ini digunakan untuk menambahakan dan mengupdate gejala-gejala penyakit ginjal yang dapat dilihat pada gambar 5 .

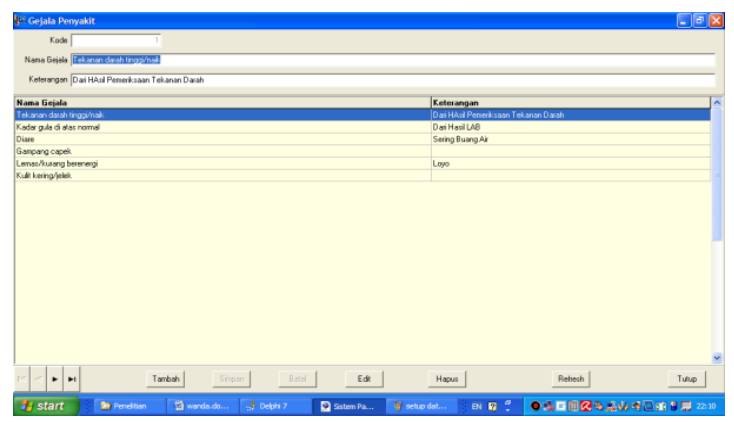

Gambar 5. Form Input Data Gejala Penyakit Ginjal

\section{Form Penginputan Jenis-Jenis Penyakit Ginjal}

Form ini dipakai untuk menginput dan update jenis-jenis penyakit ginjal. Form ini dapat dilihat pada gambar 6 .

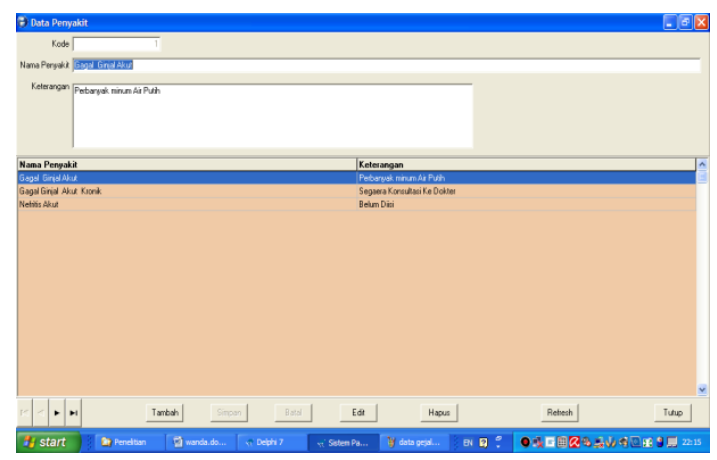

Gambar 6. Form Penginputan data Penyakit Ginjal 


\section{Form Setting Rule}

Form ini digunakan untuk melakukan setup rule berdasarkan rule-rule yang sudah ditentukan. Form ini dapat dilihat pada gambar 7.

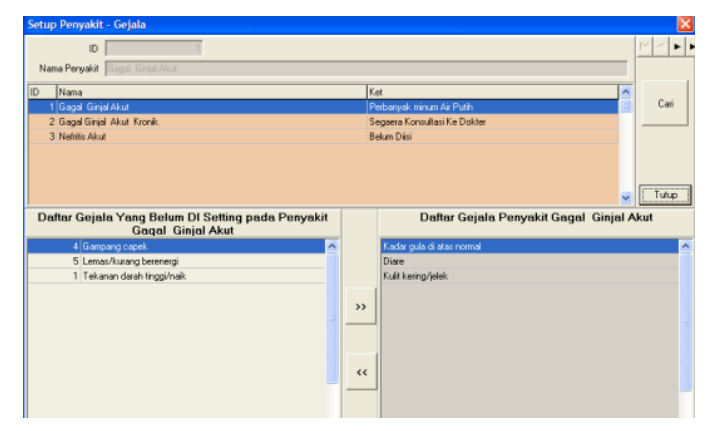

Gambar 7. Form Setup Rule

\section{Form Penginputan Data Pasien}

Form ini digunakan untuk menginput data pasien ataupun pengguna aplikasi untuk dapat melakukan proses diagnosa. Form ini dapat dilahat pada gambar 8 .

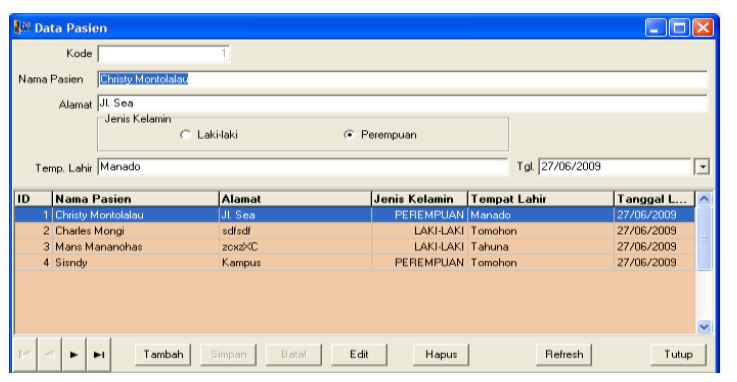

Gambar 8. Form Penginputan data Pasien

\section{Form Diagnosa}

Form ini digunakan untuk menginput data pesian yang akan melakukan proses diagnose penyakit ginjl, yang terlihat pada gambar 9 .

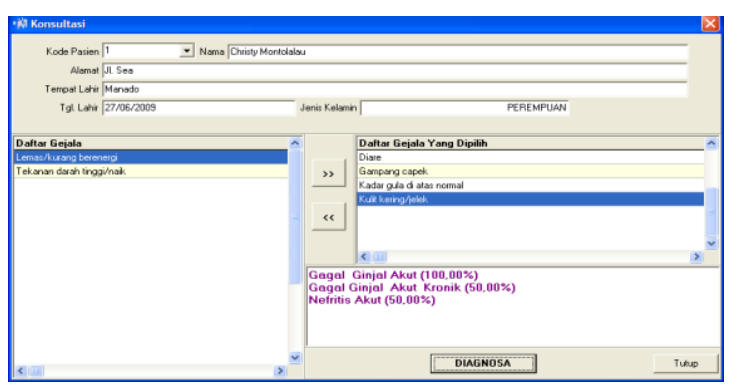

Gambar 9. Form Diagnosa

\section{KESIMPULAN}

Aplikasi system pakar pendiagnosa penyakit ginjal dapat melakukan diagnose terhadap penyakit ginjal menurut pengetahuan yang diperoleh dari pakar (dokter ahli penyakit dalam) dan diinput sebagai basis pengetahuan pada system ini.

Tingkat kepercayaan yang diperoleh dapat mewakili tingkat kepercayaan jikadiagnosa dilakukan oleh seorang pakar

\section{DAFTAR PUSTAKA}

Ignizio, J.P. 1991. Introduction to Expert System. Mcgraw - Hill,Inc, USA.

Turban, E. 1995. Decision Support and Expert System, Management Support Systems. Prentice Hall Inc, New York.

Mary Baradero, SPC, MN. 2009. Seri Asuhan Keperawatan Klien Gangguan Ginjal. Penerbit Buku Kedokteran.

Kristanto, H. 2000. Konsep dan Perancangan Database. Andi Offset, Yogyakarta.

Arhami, N. 5005. Konsep Dasar Sistem Pakar. Andi Offset, Yogyakarta. 